\title{
Effect of storage conditions on the formation of type $A$ and $B$ trichothecenes in cereal products
}

\author{
Piotr Pokrzywa ${ }^{1, A-D \oplus}$, Ewa Cieślikk ${ }^{2, E-F \oplus}$, Magdalena Surma ${ }^{2, B, D \oplus}$ \\ ${ }^{1}$ Department of Food Hygiene, Nutrition and Teaching Processes, Regional Sanitary-Epidemiological Station, Krakow, \\ Poland \\ ${ }^{2}$ Malopolska Centre of Food Monitoring, Faculty of Food Technology, University of Agriculture, Krakow, Poland \\ $A$ - Research concept and design, B - Collection and/or assembly of data, C - Data analysis and interpretation, \\ $D$ - Writing the article, $E$ - Critical revision of the article, $F$ - Final approval of article
}

Pokrzywa P, Cieślik E, Surma M. Effect of storage conditions on the formation of type A and B trichothecenes in cereal products. Ann Agric Environ Med. 2019; 260-265. doi: 10.26444/aaem/103398

\begin{abstract}
Introduction and objective. Mycotoxins are toxic metabolites produced by certain types of fungi, causing pathological changes in humans and animals. The aim of this study was to assess the degree of contamination of selected cereal grains, bran and cereal products intended for children, with mycotoxins using GCxGC-TOF-MS technique. The study involved mycotoxins belonging to the type $A$ and $B$ trichothecenes group, including T-2 toxin (T-2), HT-2 toxin (HT-2), scirpenol (SCI), 15-monoacetoxyscirpenol (15-MAS), diacetoxyscirpenol (DAS), triacetoxyscirpenol (TAS), fusarenon-X (FUS-X), nivalenol (NIV), deoxynivalenol (DON), 3-acetyl-DON (3-Ac-DON), 15-acetyl-DON (15-Ac-DON). The study also assessed the effect of conditions in which the samples were stored, including temperature $\left(6^{\circ} \mathrm{C}\right.$ and $\left.28^{\circ} \mathrm{C}\right)$ and time (14 and 28 days), on fungal growth and mycotoxin production. Among all studied compounds, only DAS and HT-2 toxins were detected in tested samples, with the exception of products intended for children. Measured HT-2 mycotoxin content in tested samples was in the range $83.9-196.4 \mathrm{\mu g} \mathrm{kg}^{-1}$.

Results and conclusions. Experiments with storage conditions showed a statistically significant increase in the HT-2 toxin level after 14 days of storage in all samples, irrespective of temperature. Prolonged storage (additional 14 days) did not cause significant changes in the HT-2 content. Further analyses showed a statistically significant effect of storage temperature on HT-2 toxin levels only in cereal products intended for children after both 14 and 28 days. Interestingly, lower temperature $\left(6^{\circ} \mathrm{C}\right)$ was more optimal then higher temperature $\left(28^{\circ} \mathrm{C}\right)$ for the HT-2 toxin production. No significant effect of storage temperature on HT-2 level was observed for cereal grains and bran.
\end{abstract}

\section{Iey words}

trichothecenes, cereals, cereal products, mycotoxin production

\section{INTRODUCTION}

Mycotoxins are toxic metabolites produced by certain types of fungi, causing pathological changes in humans, animals and plants. To-date, several hundred different toxic substances produced by fungi, including species belonging to the genera Aspergillus, Penicillium and Fusarium, have been identified [1].

For humans, the exposure is mostly by ingestion; however, in some cases, the exposure can also occur via inhalation or contact with the skin. Mycotoxins may enter the food chain indirectly and directly; indirectly, by consuming the meat or milk of animals fed with the contaminated products, or directly by consuming plant products contaminated in the field or during storage or processing. Many mycotoxins are resistant to heat processing, showing stability during standard food preparation processes. In addition, they can remain in the product long after the fungi has been destroyed. Vegetable products, such as cereals, oilseeds, coffee, fruits, spices and nuts, as well as animal products (milk, meat, offal), are all susceptible to mycotoxin contamination [2].

\footnotetext{
Address for correspondence: Piotr Pokrzywa, Regional Sanitary-Epidemiological Station in Krakow, Department of Food Hygiene, Nutrition and Teaching Processes, Pradnicka, 31-202, Cracow, Poland e-mail: p.pokrzywa@wsse.krakow.pl Received: 18.12.2018; accepted: 28.01.2019; first published: 18.03.2019
}

The Rapid Alert System for Food and Feed (RASFF) notifications regarding mycotoxin food contamination constitute a significant part of all reported food safety issues $[3,4]$. This is an important element of the food safety strategy. The RASFF system allows rapid information exchange, supports early risk prevention, as well as providing advice when initiating necessary immediate actions.

The most frequently occurring mycotoxins include aflatoxins, ochratoxin $\mathrm{A}$, and patulin, and a group of toxins produced by certain fungi species of the genus Fusarium, such as trichothecenes, fumonisins, moniliformin (MON), zearalenone (ZEA), its derivatives, and beauvericin. Trichothecenes include around 150 compounds of similar molecular structure. The most important type A trichothecenes are T-2 toxin, HT-2 toxin and diacetoxyscirpenol (DAS); Type $\mathrm{B}$ trichothecenes include deoxynivalenol (DON), nivalenol (NIV), fusarenone-X (FUS-X). Fumonisins form a group of 12 compounds, with fumonisin B1 being the most common.

Based on available data [5], a tolerable daily intake (TDI) was estimated for a cumulative dose of T-2 and HT-2 toxins, as $0.01 \mu \mathrm{g} / \mathrm{kg}$ body weight. TDI values have also been established for other trichothecenes, including DON $(1.0 \mu \mathrm{g} / \mathrm{kg}$ body weight), NIV (1.2 $\mu \mathrm{g} / \mathrm{kg}$ body weight), and most recently [6] for DAS $(0.65 \mu \mathrm{g} / \mathrm{kg}$ body weight). In 2013, the European Commission issued recommendations on the presence of T-2 and HT-2 toxin in cereals and cereal products [7]. In this document, the indicative levels were established for the 
sum of T-2 and HT-2 above which additional investigations should be performed. These values for unprocessed cereals are $1,000 \mu \mathrm{g} \mathrm{kg}^{-1}$ for oats and $100 \mu \mathrm{g} \mathrm{kg}{ }^{-1}$ for wheat. For oat bran the value is $200 \mu \mathrm{g} \mathrm{kg}^{-1}$, and for wheat bran $100 \mu \mathrm{g} \mathrm{kg}^{-1}$. The lowest value, $15 \mu \mathrm{g} \mathrm{kg}{ }^{-1}$, was determined for foods for infants and young children.

The growth of Fusarium and the production of mycotoxins, including T-2 and HT-2 toxins, depend on multiple factors, including temperature and humidity. Nazari et al. [8] reported the temperature range optimal for the growth of Fusarium langsethiae and Fusarium sporotrichioides and the production of T-2 and HT-2 toxin: $15^{\circ} \mathrm{C}$ for F. langsethiae and $10-15^{\circ} \mathrm{C}$ for F. sporotrichioides. Further study by Nazari et al. [9] determined the optimal temperature for the production of T-2 and HT-2 toxin by Fusarium langsethiae and Fusarium sporotrichioides as $14.7^{\circ} \mathrm{C}$ and $12.1^{\circ} \mathrm{C}$. However, both studies only used unprocessed cereal wheat grain as the research material. Numerous studies have been published focused on the presence of mycotoxins from the trichothecenes group in cereals and cereal products; however, data regarding contamination of cereal products intended for infants and young children are limited.

\section{OBJECTIVE}

To address the gap in the literature, the aim of this study was to assess the impact of temperature and storage duration on type A and B trichothecenes levels in cereal grains, as well as in cereal products, in particular products intended for infants and young children. Established tolerable daily intake values are referenced to assess potential risk to consumers resulting from the consumption of tested products.

\section{MATERIALS AND METHOD}

Samples. Samples consisted of cereal grains characterized by the highest consumption in Poland (wheat, oats), wheat and oat bran, as well as cereal products for children. Wheat and oat grains were obtained directly from the producers of crops harvested in south-eastern Poland. Wheat and oat bran, as well as cereal products intended for children, were purchased from retailers in Krakow. Grain products for children consisted of various differently composed instant baby porridges intended for infants from the age of 4 months, and small children. The wheat bran and oat bran selected for the study, were without any flavour additives and contained $100 \%$ of the respective type of grain. On the other hand, analysed baby cereal contained a mixture of various cereals, including wheat, oats, rye, barley and millet.

Chemicals. Trifluoroacetic acid anhydride (TFAA) and 15-Acetoxycirpenol (15-MAS) were purchased from Sigma, Krakow, Poland. N-(trimethylsilyl)-imidazol (TMSI) and trimethylchlorosilane (TMCS) were obtained for Fluka, Krakow, Poland. T2-Toxin (T-2), HT2-Toxin (HT-2), scirpenol (SCI), 15-monoacetoxyscirpenol (15MAS), diacetoxyscirpenol (DAS), triacetoxyscirpenol (TAS), fusarenon X (FUS-X), B-trichothecene-mixture solution: nivalenol (NIV), deoxynivalenol (DON), 3-acetyldeoxynivalenol (3-AcDON), 15-acetyldeoxynivalenol (15-AcDON, were purchased from Riedel-de-Haen, Germany.
Sample preparation. Research was divided into two stages. First stage included the assessment of the level of microbiological purity (total number of colonies) and degree of type A and B trichothecenes contamination in analysed cereal samples. Samples were analysed for the total number of colonies according to the method described in the standard $[10,11]$. Second stage involved only samples with confirmed presence of mould. Before storage, the moisture content of each individual sample was determined according to the method described in ISO 712:2009 Report [12].

In order to provide favourable conditions for fungal growth, the moisture content of all samples was increased to $19 \%$ by adding an appropriate amount of distilled water. Experimental samples were stored at 2 different temperatures $\left(6^{\circ} \mathrm{C}\right.$ and $\left.28^{\circ} \mathrm{C}\right)$ for 4 weeks ( 28 days). The content of $\mathrm{A}$ and $\mathrm{B}$ trichothecenes was determined in all tested samples after 14 and 28 days of storage.

Mycotoxins analysis. Samples were analysed for the presence of trichothecenes according to the report by Jelen and Wąsowicz [13]. $25 \mathrm{~g}$ of each sample were extracted in $100 \mathrm{ml}$ acetonitrile for $2 \mathrm{hrs}$, and then filtered through a paper filter.

To analyse the type A trichothecenes (T-2, HT-2, DAS, SCI, 15 MAS, TAS), $1 \mathrm{ml}$ of the filtrate was evaporated to dryness, and then re-dissolved in $200 \mathrm{ml}$ of trifluoroacetic acid (TFA). The obtained solution was heated in a thermoblock at $60^{\circ} \mathrm{C}$ for 20 minutes. After cooling, the solution was again evaporated to dryness and finally redissolved in $1 \mathrm{ml}$ of isooctane.

To analyse the type B trichothecenes (DON, 3-Ac-DON, FUS-X, NIV, 15-Ac-DON), $100 \mu \mathrm{l}$ of trimethylchlorosilane (TMCS) was added to $1 \mathrm{ml}$ of the filtrate. The obtained solution was set aside for $20 \mathrm{~min}$ at room temperature. $400 \mu \mathrm{l}$ of isooctane and $0.5 \mathrm{ml}$ of water were then added and the sample vortexed and left for 10-20 min for the layers to separate. The isooctane layer was use for the analysis.

Isooctane sample extracts were analysed using a twodimensional gas chromatograph coupled with a Time-ofFlight mass spectrometer (GCxGC-TOFMS) Pegasus 4D (Leco). Each sample was prepared in triplicate.

Equipment. Quantitative analysis was performed using 2 dimentional gas chromatograph coupled to a time of flight mass spectrometer. Analysed compounds were identified and quantified using GC $\times$ GC-ToF-MS system (Pegasus $4 \mathrm{D}$ LECO, St. Joseph, MI, USA). The GC was equipped with a DB- 5 column $(25 \mathrm{~m} \times 0.2 \mathrm{~mm} \times 0.33 \mu \mathrm{m}$, Agilent Technologies, Santa Clara, CA, USA) and Rxi ${ }^{\oplus}-17(1.2 \mathrm{~m} \times 0.1 \mathrm{~mm} \times 0.1 \mu \mathrm{m}$, Restek Bellefonte, PA) as a second column. Main oven temperature was $80^{\circ} \mathrm{C}(1 \mathrm{~min})$, then increased $20^{\circ} \mathrm{C} / \mathrm{min}$ to $170^{\circ} \mathrm{C} / 3 \mathrm{~min}$, then increased $4{ }^{\circ} \mathrm{C} / \mathrm{min}$ to $240^{\circ} \mathrm{C} / 4 \mathrm{~min}$, and $10^{\circ} \mathrm{C} / \mathrm{min}$ to $270^{\circ} \mathrm{C} / 5 \mathrm{~min}$. A secondary oven was run at temperatures $10^{\circ} \mathrm{C}$ higher than in the first. Transfer line was $290^{\circ} \mathrm{C}$. Injection port temperature $-280^{\circ} \mathrm{C}$, splitless mode $(60 \mathrm{~s})$, helium flow $-0.8 \mathrm{ml} / \mathrm{min}$, ion source temperature $240^{\circ} \mathrm{C}$. Spectra were collected at a rate $50 \mathrm{scans} / \mathrm{s}$ in a range of 100-700 Da. For 2 dimensional analysis modulation, time was optimized and set at $5 \mathrm{~s}$.

Statistical analysis. Results were analysed using two-way analysis of variance (ANOVA) with a significance level of $\mathrm{p}<0.05$. 


\section{RESULTS AND DISCUSSION}

The total colony-forming unit count in tested samples was in range of 54 individual colonies to $4.3 \times 10^{5} \mathrm{CFU}$. The lowest level of contamination was found in a sample from a cereal product for children in the range from 54-75 CFU; mean content $-65 \pm 10 \mathrm{CFU}$. The highest level of contamination was found in cereal grains; in general, higher in oat grain with a mean value $3.9 \times 10^{5} \pm 4.1 \times 10^{4} \mathrm{CFU}$, in the range $4.3 \times 10^{5}-3.5 \times 10^{5} \mathrm{CFU}$ than in wheat with a mean content $2.9 \times 10^{5} \pm 3.2 \times 10^{4} \mathrm{CFU}$, in the range from $2.5 \times 10^{5}-3.2 \times 10^{5}$ CFU. Finally, the colonies count in wheat and oat bran samples was lower than for cereal grains, and the mean value was $2.2 \times 10^{3} \pm 4,4 \times 10^{2} \mathrm{CFU}$, in the range $1.8 \times 10^{3}-2.8 \times 10^{3}$ $\mathrm{CFU}$, and with a mean value of $2.7 \times 10^{3} \pm 3 . \times 10^{2} \mathrm{CFU}$, in the range from $2.6 \times 10^{3}$ to $3.2 \times 10^{3}$ [CFU], respectively.

The moisture content of the tested samples, respectively, was $3.8 \%$ for cereals, $7.8 \%$ for bran, and $3.5 \%$ for cereal products for children.

Among all studied type A trichothecenes, only DAS and HT-2 toxins were detected in tested samples. Measured HT-2 mycotoxin content in tested samples was in the range of 83.9 - $196.4 \mu \mathrm{g} \mathrm{kg}^{-1}$ product (Tab. 1). The HT-2 toxin was identified only in 2 out of 8 tested wheat samples (mean $84.7 \mu \mathrm{g} \mathrm{kg}^{-1}$ ) and in 4 out of 8 oat samples (mean $126.7 \mu \mathrm{g} \mathrm{kg}^{-1}$ ). Similarly, HT-2 toxin was found in 2 out of the 8 wheat bran samples (mean $189.3 \mu \mathrm{g} \mathrm{kg}^{-1}$ ) and in 2 out of 8 oat bran samples (mean $\left.102.1 \mu \mathrm{g} \mathrm{kg}^{-1}\right)$.

The DAS toxin was determined in only 2 out of 8 wheat grain samples (mean of $16.6 \mu \mathrm{g} \mathrm{kg}^{-1}$ ).

Finally, no trichothecenes were found in tested cereal products for children. The determined contents of HT-2 mycotoxin in wheat samples were higher than the values reported by Alkadri et al. [14] in wheat from Italy and Syria, ranging from $2-32 \mu \mathrm{g} \mathrm{kg}^{-1}$. Also, the level of wheat contamination with this toxin was lower in studies by Lindblad et al. [15] concerning the occurrence of fusarium toxins in wheat in Sweden, where its presence was detected in only 3 samples.

Lower values were also found in the studies conducted by Stuper-Szablewska and Perkowski [16] concerning wheat contamination in Poland, and by Suproniene et al. [17] in Lithuania. Similarly, the content of HT-2 toxin in wheat purchased from local stores in Italy was lower and in the range of $6.78 \mu \mathrm{g} \mathrm{kg}^{-1}-60.10 \mu \mathrm{g} \mathrm{kg}^{-1}$ [18]. Much lower HT-2 mycotoxin levels were also found in wheat and oat grain from areas of Slovenia [19] and Croatia [20], and cereal products in Poland [21], in which the last toxins T-2 and HT-2 were found in $43 \%$ of the samples tested. The results for wheat and oat bran samples showed higher levels of HT-2 toxin that those reported by Rodrigeuez-Carrasco et al. [22]. On the other hand, significantly higher levels of HT-2 mycotoxin $\left(113 \mu \mathrm{g} \mathrm{kg}^{-1}-647 \mu \mathrm{g} \mathrm{kg}^{-1}\right)$ were found in oat grain samples harvested in south-eastern Poland [23] and in Sweden [24]. Finally, even higher levels of mycotoxins were found in wheat grain and flour by Stanciu et al. [25], including DON toxin in 8 samples $\left(110-1,787 \mu \mathrm{g} \mathrm{kg}^{-1}\right)$.

It should be emphasized that no trichothecenes were found in any of the samples of cereal products intended for children. This is important from the point of food safety for a particularly sensitive consumer, where even small amounts can pose a health risk. However, studies exist that showed different results. Results published by Oueslati et al. [26] showed a contamination of cereal products intended for children with DON $\left(5-110 \mu \mathrm{g} \mathrm{kg}^{-1}\right), 15-\mathrm{Ac}-\mathrm{DON}\left(9-20 \mu \mathrm{g} \mathrm{kg}^{-1}\right)$ and HT-2 (149-209 $\left.\mu \mathrm{g} \mathrm{kg}^{-1}\right)$.

Fungal growth and production of mycotoxins in cereal grains and cereal products may be influenced by various factors, including product moisture content and air humidity, as well as the temperature [27]. To investigate the effect of temperature and storage duration on tested samples (moisture content at 19\%) mycotoxins levels, the experiment was carried at 2 different temperatures $\left(6^{\circ} \mathrm{C}\right.$ and $\left.28^{\circ} \mathrm{C}\right)$, and lasting 28 days. The mycotoxin content was analysed twice, after 14 and 28 days. Changes in the HT-2 toxin content in samples when stored at $6^{\circ} \mathrm{C}$ are shown in Table 2, while results for $28^{\circ} \mathrm{C}$ are shown in Table 3 .

After 14 days of samples storage at $6^{\circ} \mathrm{C}$, results showed a statistically significant increase in the level of HT-2 toxin in all groups of samples. A $21.1 \%$ increase in the content of HT-2 toxin in cereal grain samples and a $64.9 \%$ increase in bran, compared to the level of mycotoxins in samples prior

Table 1. Trichothecenes content in analysed cereal samples

\begin{tabular}{|c|c|c|c|c|c|c|c|c|}
\hline \multirow[b]{2}{*}{ Mycotoxin } & \multirow[b]{2}{*}{$\operatorname{LOD}[\mu \mathrm{g} / \mathrm{kg}]$} & \multirow[b]{2}{*}{$\mathrm{LOQ}[\mu \mathrm{g} / \mathrm{kg}]$} & & \multicolumn{5}{|c|}{ Trichothecenes content [ $\mu \mathrm{g} \mathrm{kg}-1]$} \\
\hline & & & \multirow{10}{*}{$\begin{array}{l}\text { Mean } \\
\text { range }\end{array}$} & Wheat $(n=8)$ & Oats (n-8) & Wheat bran $(n=8)$ & Oat bran $(n=8)$ & $\begin{array}{l}\text { Cereal products intended } \\
\quad \text { for children }(n=8)\end{array}$ \\
\hline HT-2 & 0,01 & 0.03 & & $\begin{array}{l}84.7 \pm 1.1 \\
83.9-85.5\end{array}$ & $\begin{array}{l}126.7 \pm 44.4 \\
85.6-167.9\end{array}$ & $\begin{array}{c}189.3 \pm 10.1 \\
182.1-196.4\end{array}$ & $\begin{array}{c}102.1 \pm 5.3 \\
98.3-105.8\end{array}$ & nd \\
\hline DAS & 0.01 & 0.03 & & $\begin{array}{c}166.6 \pm 13.7 \\
156.9-176.3\end{array}$ & nd & nd & nd & nd \\
\hline $\mathrm{SCl}$ & 0.01 & 0.03 & & nd & nd & nd & nd & nd \\
\hline 15-MAS & 0.03 & 0.08 & & nd & nd & nd & nd & nd \\
\hline TAS & 0.05 & 0.15 & & nd & nd & nd & nd & nd \\
\hline DON & 0.03 & 0.08 & & nd & nd & nd & nd & nd \\
\hline 3-AcDON & 0.05 & 0.15 & & nd & nd & nd & nd & nd \\
\hline NIV & 0.01 & 0.03 & & nd & nd & nd & nd & nd \\
\hline FUS-X & 0,05 & 0.15 & & nd & nd & nd & nd & nd \\
\hline
\end{tabular}

nd - non-detected $(<\mathrm{LOQ})$ 
Table 2. Changes in HT-2 toxin content in samples when stored at $6^{\circ} \mathrm{C}\left[\mu \mathrm{g} \mathrm{kg}{ }^{-1}\right]$

\begin{tabular}{|c|c|c|c|c|c|}
\hline & \multirow{2}{*}{ Tested samples } & \multirow{2}{*}{ No. of samples } & \multicolumn{3}{|c|}{ HT-2 content during storage } \\
\hline & & & Before storage & 14 days & 28 days \\
\hline \multirow{3}{*}{$\begin{array}{c}\text { Mean range } \\
\text { Positive samples } \\
\%\end{array}$} & $\begin{array}{c}\text { Cereals } \\
\text { Wheat } \\
\text { Oat }\end{array}$ & $\begin{array}{l}8 \\
8\end{array}$ & $\begin{array}{c}84.7^{\mathrm{a}} \pm 1.13 \\
83.9-85.5 \\
25 \% \\
126.8^{\mathrm{a}} \pm 10.1 \\
85.6-167.9 \\
50 \%\end{array}$ & $\begin{array}{c}88.6^{b} \pm 4.47 \\
78.7-93.7 \\
100 \% \\
119.9^{b} \pm 48.1 \\
72.1-180.6 \\
100 \%\end{array}$ & $\begin{array}{c}88.9^{\mathrm{b}} \pm 3.00 \\
82.9-92.4 \\
100 \% \\
119.4^{\mathrm{b}} \pm 43.6 \\
86.6-199.0 \\
100 \%\end{array}$ \\
\hline & $\begin{array}{c}\text { Bran } \\
\text { Wheat bran } \\
\text { Oat bran }\end{array}$ & $\begin{array}{l}8 \\
8\end{array}$ & $\begin{array}{c}189.3^{\mathrm{a}} \pm 10.1 \\
182.1-196.4 \\
25 \% \\
102.1^{\mathrm{a}} \pm 5.3 \\
98.3-105.8 \\
25 \%\end{array}$ & $\begin{array}{c}142.2^{\mathrm{b}} \pm 34.3 \\
100.7-195.5 \\
100 \% \\
106.4^{\mathrm{b}} \pm 8.85 \\
98.7-119.8 \\
100 \%\end{array}$ & $\begin{array}{c}151.7^{\mathrm{b}} \pm 23.6 \\
126.1-189.3 \\
100 \% \\
108.6^{\mathrm{b}} \pm 6.88 \\
105.2-118.9 \\
100 \%\end{array}$ \\
\hline & $\begin{array}{l}\text { Cereal products intended for children } \\
\text { Cereal products intended for children }\end{array}$ & 8 & nd & $\begin{array}{c}12.5^{\mathrm{a}} \pm 1.67 \\
10.3-14.9 \\
100 \%\end{array}$ & $\begin{array}{c}13.1^{\mathrm{a}} \pm 1.44 \\
10.9-14.9 \\
100 \%\end{array}$ \\
\hline
\end{tabular}

nd - non detected $(<L O Q)$

$a, b$ - statistically significant difference between mean values designated by the identical letters in rows $p<0.05$

Table 3. Changes in HT-2 toxin content in samples when stored at $28^{\circ} \mathrm{C}\left[\mu \mathrm{g} \mathrm{kg}^{-1}\right]$.

\begin{tabular}{|c|c|c|c|c|c|}
\hline & \multirow{2}{*}{ Tested samples } & \multirow{2}{*}{ No. of samples } & \multicolumn{3}{|c|}{ HT-2 content during storage } \\
\hline & & & Before storage & 14 days & 28 days \\
\hline & $\begin{array}{c}\text { Cereals } \\
\text { Wheat } \\
\text { Oat }\end{array}$ & $\begin{array}{l}8 \\
8\end{array}$ & $\begin{array}{c}84.7^{\mathrm{a}} \pm 1.13 \\
83.9-85.5 \\
25 \% \\
126.8^{\mathrm{a}} \pm 44.4 \\
85.6-167.9 \\
50 \%\end{array}$ & $\begin{array}{c}87.7^{b} \pm 3.69 \\
80.7-91.3 \\
100 \% \\
109.7^{b} \pm 34.9 \\
86.2-175.6 \\
100 \%\end{array}$ & $\begin{array}{c}88.1^{\mathrm{b}} \pm 3.09 \\
82.9-91.9 \\
100 \% \\
119.4^{\mathrm{b}} \pm 43.6 \\
87.5-175.4 \\
100 \%\end{array}$ \\
\hline \multirow[t]{2}{*}{$\%$} & $\begin{array}{c}\text { Bran } \\
\text { Wheat bran } \\
\text { Oat bran }\end{array}$ & $\begin{array}{l}8 \\
8\end{array}$ & $\begin{array}{c}189.3^{\mathrm{a}} \pm 10.1 \\
182.1-196.4 \\
25 \% \\
102.1^{\mathrm{a}} \pm 5.3 \\
98.3^{-105.8} \\
25 \%\end{array}$ & $\begin{array}{c}167.3^{b} \pm 11.7 \\
153.3-185.0 \\
100 \% \\
105.1^{b} \pm 5.82 \\
100.1-111.7 \\
100 \%\end{array}$ & $\begin{array}{c}167.8^{b} \pm 13.1 \\
151.7-187.0 \\
100 \% \\
104.7^{b} \pm 9.5 \\
90.2-113.6 \\
100 \%\end{array}$ \\
\hline & $\begin{array}{l}\text { Cereal products intended for children } \\
\text { Cereal products intended for children }\end{array}$ & 8 & nd & $\begin{array}{c}8.79^{a} \pm 0.93 \\
7.4-10.2 \\
100 \%\end{array}$ & $\begin{array}{c}8.60^{\mathrm{a}} \pm 0.62 \\
7.6-9.6 \\
100 \%\end{array}$ \\
\hline
\end{tabular}

nd - non detected (<LOQ)

$a, b-$ statistically significant difference between mean values designated by the identical letters in rows $p<0.05$

to storage. More importantly, this increase was also observed in samples of cereal products intended for children.

While the content of mycotoxins was below the level of quantification before the storage, 14-day storage resulted in an average increase to $12.5 \mu \mathrm{g} \mathrm{kg}^{-1}$ (Tab. 3). Overall, the mycotoxin contents found in stored wheat samples were close $(89 \%)$ to the indicative values $\left(100 \mu \mathrm{g} \mathrm{kg}^{-1}\right)$ set by the European Commission for the T-2 and HT-2 toxins in cereals and cereal products [7]. However, for oats the results were almost 10 times lower than the index value $\left(1,000 \mu \mathrm{g} \mathrm{kg}^{-1}\right)$. For processed cereal products, such as bran and cereal products for children, only wheat bran exceeded the $100 \mu \mathrm{g} \mathrm{kg}^{-1}$ index value (142\% of the index value). A lower contamination level was measured for oat bran ( $71 \%$ of the index value). Finally, the HT-2 level in cereal products for children was lower than the indicative value set at $15 \mu \mathrm{g} \mathrm{kg}^{-1}$ ( $83 \%$ of the index value).

Similar to the results for storage at $28^{\circ} \mathrm{C}, 14$-day storage at $28^{\circ} \mathrm{C}$ of the tested samples resulted in a statistically significant increase in the level of HT-2 toxin. There was a $16 \%$ increase in the content of HT-2 toxin in cereal samples, and a $90.7 \%$ increase in bran samples, compared to the level of mycotoxins in samples prior to storage. Again, this increase was also observed in samples of cereal products intended for children. While the content of mycotoxins was below the level of quantification before the storage, 14-day storage resulted in an average increase to $8.8 \mu \mathrm{g} \mathrm{kg}^{-1}$ (Tab. 4).

Comparison of the obtained results with published index values showed a similar trend to that of samples stored at $6^{\circ} \mathrm{C}$. For wheat cereal grains the mycotoxin content was $88 \%$ of the index value, while for oats $-10 \%$ of the index value. Only wheat bran exceeded (167\%) the index value. Oat bran was $52.5 \%$, and cereal products for children $59 \%$ of their respective index values. In addition, the values for all tested product groups were lower than the values obtained for samples stored at $6^{\circ} \mathrm{C}$.

Results obtained by Nazari et al. [8] showed a statistically significant increase in the level of T-2 and HT-2 toxin produced by Fusarium sporotrichioides throughout the storage period (1 - 30 days). However, for Fusarium langsethiae, no significant effect of storage time on toxin production was observed. Casquete et al. [28] studied the effect of physicochemical factors on fungal growth and production of mycotoxins by Aspergillus flavus. They found that 4-day-long storage at different temperatures significantly increased the levels of aflatoxins B1. Then, depending on the test strain and storage temperature, the level of this toxin did not change 
Table 4a. TDI values for HT-2 toxin for bran and cereal products intended for children relative to the body weight of infants and children

\begin{tabular}{|c|c|c|c|c|c|c|}
\hline \multirow{2}{*}{$\begin{array}{l}\text { Cereal } \\
\text { product }\end{array}$} & \multirow{2}{*}{$\begin{array}{c}\text { Portion } \\
\text { size }\end{array}$} & \multicolumn{5}{|c|}{ \%TDI relative to the body weight } \\
\hline & & A & B & C & $\mathrm{D}$ & $E$ \\
\hline Wheat bran & $12 \mathrm{~g}^{*}$ & $-{ }^{* *}$ & $-{ }^{* *}$ & 1060 & 530 & 544 \\
\hline Oat bran & $20 \mathrm{~g}^{*}$ & $-{ }^{* * *}$ & $-{ }^{* *}$ & 1143 & 572 & 587 \\
\hline $\begin{array}{l}\text { Cereal products indended for } \\
\text { children }\end{array}$ & $25 \mathrm{~g}^{*}$ & 364 & 273 & $-{ }^{* *}$ & $-{ }_{-*}^{* *}$ & $--^{* *}$ \\
\hline
\end{tabular}

* portion size recommended by the producer

** due to the intended use of the product, the TDI values were not calculated

Table 4b. TDI values for HT-2 toxin for bran and cereal products for children relative to the body weight of young adults and adults

\begin{tabular}{lccccc}
\hline \multirow{2}{*}{$\begin{array}{l}\text { Cereal } \\
\text { product }\end{array}$} & Portion & \multicolumn{4}{c}{ \%TDI relative to the body weight } \\
\cline { 3 - 6 } & size & $\mathrm{F}$ & $\mathrm{G}$ & $\mathrm{H}$ & $\mathrm{I}$ \\
\hline Wheat bran & $12 \mathrm{~g}^{*}$ & 301 & 360 & 288 & 322 \\
\hline Oat bran & $20 \mathrm{~g}^{*}$ & 324 & 388 & 869 & 348 \\
\hline
\end{tabular}

* portion size recommended by the producer

significantly throughout the 12- day experiment. Finally, regardless of the storage temperature, no significant changes in the levels of HT-2 toxin were observed in all samples after 28 days of storage.

The current study also assessed the impact of storage temperature of the tested samples on the level of HT-2 toxin. No significant changes were recorded for cereals and bran. However, a statistically significant difference was found for the levels of HT-2 toxin, depending on the temperature during the storage of cereal products for children. During storage for 14 days and 28 days, a temperature of $6^{\circ} \mathrm{C}$ was more favourable for the production of HT-2 toxin.

The obtained results for the current study showed that storage of cereal products at $6^{\circ} \mathrm{C}$ was more favourable for the production of HT-2 toxin. Kokkonen et al. [29] also reported that a temperature of $15^{\circ} \mathrm{C}$ was more optimal for the production of group A trichlters, compared to $25^{\circ} \mathrm{C}$. Nazari et al. [8] also found an optimal temperature for production of the HT-2 toxin by Fusarium langsethiae at $15^{\circ} \mathrm{C}$, and for Fusarium sporotrichioides around $10-15^{\circ} \mathrm{C}$. However, Mylon and Magan [30] showed quite the opposite. Authors studied the optimal temperature for the production of T-2 and HT-2 toxin by Fusarium langsethiae during oat grain storage with various water activity at 4 temperature ranges: $15^{\circ} \mathrm{C}, 20^{\circ} \mathrm{C}$, $25^{\circ} \mathrm{C}, 30^{\circ} \mathrm{C}$. Results showed $25^{\circ} \mathrm{C}$ to be most optimal. In addition, storing oats at a higher temperature range, such as $20-30^{\circ} \mathrm{C}$ in the Medina and Magan [31] study, was determined as optimal for the production of T-2 and HT-2 toxin by Fusarium langsethiae for aqueous activity of 0.98-0.995.

Based on the obtained results, the risk for consumers resulting from the consumption of cereal products in relation to the value of tolerable daily intake (TDI) was estimated. The calculated values are expressed as \% TDI (Tab. 4a, 4b). The calculations were made based on the maximum values of HT-2 toxin measured during the experiment (wheat bran after 28 days storage at $28^{\circ} \mathrm{C}$, oat bran after 28 days storage at $6^{\circ} \mathrm{C}$ and cereal products for children after 28 days storage at $6^{\circ} \mathrm{C}$ ), and the values of average body weight adopted from the nutrition standards for the Polish population: infants aged $0.5-1-9.0 \mathrm{~kg}(\mathrm{~A})$, small children aged $1-3$ years $-12 \mathrm{~kg}(\mathrm{~B})$, children aged 4-6 - $19 \mathrm{~kg}(\mathrm{C})$, boys aged $10-12-38 \mathrm{~kg}(\mathrm{D})$, girls $10-12$ years $-37 \mathrm{~kg}$ (E) boys aged $16-18$ years $-67 \mathrm{~kg}$
(F), girls 16-18 years - $56 \mathrm{~kg}(\mathrm{G})$, men - $70 \mathrm{~kg}(\mathrm{H})$, women - $62.5 \mathrm{~kg}$ (I) [28].

Daily intake of HT-2 toxin with cereal products such as wheat and oat bran or cereal products for children, stored under the conditions described in the study, exceeded the TDI value many times relative to the average body weight. In addition, only one portion size recommended for consumption by the producer was sufficient to exceed that value.

\section{CONCLUSIONS}

In all tested samples, prolonged storage at $19 \%$ humidity for 14 days, both at $6^{\circ} \mathrm{C}$ and $28^{\circ} \mathrm{C}$, resulted in a statistically significant increase in the level of HT-2 toxin. Thus, storage of cereal products under favourable conditions, including high air humidity that can lead to an increase in the moisture content, may promote the formation of HT-2 toxin. Further storage of samples at both $6^{\circ} \mathrm{C}$ and $28^{\circ} \mathrm{C}$ did not result in an increase in HT-2 toxin level.

Notably, even 14 days were sufficient for the formation of HT-2 toxin in amounts posing a risk to the consumer. It is common that cereal products (cereal bran, cereal, porridge for small children) after being opened in an individual household are stored in the original packaging for much longer than 14 days.

The presented results show a statistically significant negative effect of storage temperature on HT-2 mycotoxin levels in cereal products for children. This effect was observed after storage for 14 days and 28 days.

Finally, the results showed that a low temperature of $6{ }^{\circ} \mathrm{C}$ was more conducive to the production of HT-2 toxin than a higher temperature of $28^{\circ} \mathrm{C}$. There was no significant effect of temperature on the level of HT-2 toxin in cereal grain and bran samples.

This work is a part of PhD thesis of Piotr Pokrzywa.

\section{REFERENCES}

1. Reddy K, Salleh B, Saad B, Abbas HK, Abel CA, Shier WT. An overview of mycotoxin contamination in foods and its implications for human health. Toxin Rev. 2010; 29: 3-26.

2. Bhupendra S, Kharayat,Yogendra Singh. Mycotoxins in Foods: Mycotoxicoses, Detection, and Management Microbial Contamination and Food Degradation, A volume in Handbook of Food Bioengineering 2018: 395-421.

3. European Commission, Health and Food Safety. RASFF - The Rapid Alert System for Food and Feed - 2016. Annual. 2017. https://ec.europa. eu/food/sites/food/files/safety/docs/rasff_annual_report_2016.pdf. (access: 2018.06.22)

4. European Commission, Health and Food Safety. RASFF - The Rapid Alert System for Food and Feed - 2015. Annual; 2016. https://ec.europa. eu/food/sites/food/files/safety/docs/rasff_annual_report_2015.pdf. (access: 2018.06.22)

5. EFSA Panel on Contaminants in the Food Chain. Scientific Opinion on the risks for animal and public health related to the presence of T-2 and HT-2 toxin in food and feed. EFSA J. 2011; 9: 2481.

6. EFSA Panel on Contaminants in the Food Chain. Risk to human and animal health related to the presence of 4,15-diacetoxyscirpenol in food and feed. EFSA J. 2018; 16(8): 5367.

7. European Commission, Commission Recommendation of 27 March 2013 on the presence of T-2 and HT-2 toxin in cereals and cereal products. 2013/165/UE.

8. Nazari L, Pattori E, Terzi V, Morcia C, Rossi V. Influence of temperature on infection, growth, and mycotoxin production by Fusarium langsethiae and F. sporotrichioides in durum wheat, Food Microbiol. 2014; 39: 19-26. 
9. Nazari L, Manstretta V, Rossi V. A non-linear model for temperaturedependent sporulation and T-2 and HT-2 production of Fusarium langsethiae and Fusarium sporotrichioides. Fungal Biol. 2016; 120: $562-571$.

10. ISO 21527-2:2009 Microbiology of food and animal feeding stuffs Horizontal method for the enumeration of yeasts and moulds - Part 1 : Colony count technique in products with water activity less than or equal to 0,95 .

11. ISO 21527-1:2009 Microbiology of food and animal feeding stuffs Horizontal method for the enumeration of yeasts and moulds - Part 1 : Colony count technique in products with water activity greater than 0,95 .

12. ISO 712:2009. Cereals and cereal products - Determination of moisture content - Reference method

13. Jeleń $H H$, Wąsowicz E. Determination of trichothecenes in wheat grain without sample cleanup using comprehensive two-dimensional gas chromatography-time-of-flight mass spectrometry. J Chromatography A. 2008 ; 1215: 203-207.

14. Alkadri D, Rubert J, Prodi A, Pisi A, Manes J, Soler C. Natural cooccurrence of mycotoxins in wheat grains from Italy and Syria. Food Chem. 2014; 157: 111-118.

15. Lindblad M, Gidlund A, Sulyok M, Börjesson T, Krska R, Olsen M, Fredlund E. Deoxynivalenol and other selected Fusarium toxins in Swedish wheat. Occurrence and correlation to specific Fusarium species. Internat J Food Microbiol. 2013; 167: 284-291.

16. Stuper-Szablewska K, Perkowski J. Contamination of wheat grain with microscopic fungi and their metabolites in Poland in 2006-2009. Ann Agric Environ Med. 2014; 21(3): 504-509.

17. Suproniene S, Justesen AJ, Nicolaisen M, Mankeviciene A, Dabkevicius Z, Semaskiene R, Leistrumaite A. Distribution of trichothecene and zearalenone producing Fusarium species In grain of different cereal species and cultivars grown under organic farming conditions in Lithuania. Ann Agric Environ Med. 2010; 17: 79-86.

18. Juan C, Ritieni A, Mańes J. Occurrence of Fusarium mycotoxins in Italian cereal and cereal products from organic farming. Food Chem. 2013; 141: 1747-1755.

19. Kirincic S, Skrjanc B, Kos N, Kozolc B, Pirnat N, Tavcar-Kalcher G. Mycotoxins in cereals and cereal products in Slovenia. Official control of foods in the years 2008-2012. Food Control. 2015; 50: 157-165.

20. Pleadin J, Vahcic N, Persi N, Sevelj D, Markov K, Frece J. Fusarium mycotoxins' occurrence in cereals harvested from Croatian Fields. Food Control 2013; 32: 49-54
21. Postupolski J, Rybińska K, Ledzion E, Kurpińska-Jaworska J, Szczęsna $\mathrm{M}$, Karłowski K. Monitoring programme of $\mathrm{H}-2$ and HT-2 toxins level in cereal products. Annalas o the Nat Instit Hygiene. 2008; 59(4): 429-435.

22. Rodríguez-Carrasco Y, José Ruiz M, Font G, Berrada H. Exposure estimates to Fusarium mycotoxins through cereals intake. Chemosphere. 2013; 93: 2297-2303.

23. Kuzdraliński A, Solarska E, Mazurkiewicz J. Mycotoxin content of organic and conventional oats from southeastern Poland. Food Control. 2013; 33: 68-72.

24. Fredlund E, Gidlund A, Sulyok M, Börjesson T, Krska R, Olsen M, Lindblad M. Deoxynivalenol and other selected Fusarium toxins in Swedish oats - Occurrence and correlation to specific Fusarium species. Int J Food Microbiol. 2013; 167: 276-283.

25. Stanciu O, Juan C, Miere D, Loghin F, Manes J. Occurrence and cooccurrence of Fusarium mycotoxins in wheat grains and wheat flour from Romania. Food Control. 2017; 73: 147-155.

26. Oueslati S, Berrada H, Manes J, Juan C. Presence of mycotoxins in Tunisian infant foods samples and subsequent risk assessment. Food Control. 2018; 84: 362-369.

27. Cendoya E, Monge MP, Chiacchiera SM, Farnochia MC, Ramirez ML. Influence of water activity and temperature on growth and fumonisin production by Fusarium proliferatum strains on irradiated wheat grains. Int J Food Microbiol. 2018; 266: 158-166.

28. Casquete R,Benito MJ, Córdoba M, Ruiz-Moyano S, Martín A. The growth and aflatoxin production of Aspergillus flavus strains on a cheese model system are influenced by physicochemical factors. J Dairy Sci. 2017; 100: 6987-6996.

29. Kokkonen M, Ojala L, Parikka P, Jestoi M. Mycotoxin production of selected Fusarium species at different culture conditions. Int J Food Microbiol. 2010; 143: 17-25.

30. Mylona K, Magan N. Fusarium langsethiae: Storage environment influences dry matter losses and T2 and HT-2 toxin contamination of oats. J Stored Prod Res. 2011; 47: 321-327.

31. Medina A, Magan N. Temperature and water activity effects on production of T-2 and HT-2 by Fusarium lngsethiae strains from north European countries. Food Microbiol. 2011; 28: 392-398.

32. Jarosz M. Nutritional norms for the Polish population - amendment. Instytut Żywności i Żywienia 2012, www.izz.waw.pl/attachments/ article/33/NormyZywieniaNowelizacjaIZZ2012.pdf. (access: 2018.06.22)

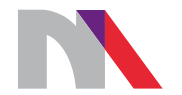

Ministry of Science and Higher Education

Republic of Poland

Generation of the DOI (Digital Object Identifier) - task financed under the agreement No. 618/P-DUN/2019 by the Minister of Science and Higher Education 